DOI: $10.2478 / \mathrm{v} 10122-009-0003-0$

\title{
ADJECTIVES IN HYPOTAXIS: PROPOSED DIMENSIONS FOR A DESCRIPTION OF SYNTAGMS IN MODERN WRITTEN ARABIC
}

\author{
MARCIN MICHALSKI
}

\begin{abstract}
Marcin Michalski. Adjectives in Hypotaxis: Proposed Dimensions for a Description of Syntagms in Modern Written Arabic. Lingua Posnaniensis, vol. LI/2009. The Poznan Society for the Advancement of the Arts and Sciences. PL ISSN 0079-4740, ISBN 978-83-7654-080-1, pp. 39-56
\end{abstract}

The purpose of this paper is to propose dimensions enabling a systematic description of biconstituent hypotactic adjectival syntagms in Modern Written Arabic. A dimension is conceived of as a set of homegeneous properties characterizing syntagms. A biconstituent hypotactic adjectival syntagm is a complex lingual sign constituted by two words that are bound by the relation of qualification; "adjectival" means that at least one of these words is an adjective. Adjectives are identified as a separate part of speech on the grounds of their attributive capability and concord with the qualified substantive.

Nine dimensions are proposed that make it possible to characterize syntagms with regard to properties of their adjectival constituent, morphological indicators of qualification, linear properties, syntactic function of their constituents and reducibility of a syntagm to its qualificatum. The dimensions and properties they contain can be used for conducting a characterization of any biconstituent hypotactic adjectival syntagm, i.e. determining a set of nine properties it shows with regard to all nine dimensions.

Marcin Michalski, Institute of Linguistics, Adam Mickiewicz University, al. Niepodległości 4, PL - 61-874 Poznań

\section{INTRODUCTION*}

Modern Written Arabic ${ }^{1}$ (henceforth MWA) is a language with a great variety of hypotactic syntagms that are characterized by numerous kinds of properties. These properties may derive from the kind of morphological indicators of qualification between their constituents (i.e. words constituting the syntagm), the linear order of the constituents, the parts

* The author would like to express his gratitude to Prof. Jerzy Bańczerowski (Institute of Linguistics, Adam Mickiewicz University, Poznań) for his reading of the manuscript and valuable suggestions on its content. The author also wishes to thank John William Strnad, M.A. (Institute of Linguistics, Adam Mickiewicz University, Poznań) for his kind revision of the English of this paper. Any mistakes and inconsistencies are solely the author's responsibility.

${ }^{1}$ In nominal morphology, Modern Written Arabic has three cases: nominative (NOM, e.g. baytun 'a house'), genitive (GEN, e.g. baytin 'of a house') and accusative (ACC, e.g. baytan 'a house'); three numbers: singular (SG, e.g. baytun), dual (DU, e.g. baytāni 'two houses'), plural (PL, e.g. buyūtun 'houses'). As for gender, it seems justified to distinguish not only masculine (M, e.g. riğālun 'men') and feminine (F, e.g. nisā'un 'women'), but also non-human gender for plural nouns (substantives, adjectives, pronouns) and verbs designating non-human objects 
of speech to which the constituents belong, the syntactic functions the constituents have, and some others. In order for this fragment of syntax of this language to be adequately described, an appropriate apparatus, with clearly explained and consistently used concepts and terms, is needed. Current descriptions of MWA syntax rarely fulfil this requirement. The aim of this article is to propose such an apparatus in the form of a set of properties, classified into nine dimensions (parameters), that enable a systematic description and a classification of a subset of MWA hypotactic syntagms, namely hypotactic syntagms composed of two constituents at least one of which is an adjective. These will be referred to as biconstituent hypotactic adjectival syntagms. $^{2}$

Before starting the discussion of syntagms as language signs composed of words, it will first be explained how the concept of word is understood in this paper. Then, the concepts of qualification, hypotactic syntagm and adjectival syntagm will be explained. The latter will require an, of necessity, brief discussion of which nouns, i.e. nominal parts of speech, are adjectives in MWA, as distinct from substantives.

For the purposes of this paper, word is understood in accordance with the concept proposed by BAŃCZEROWSKI (1997a and b) $)^{3}$, i.e. as "a minimal unit of syntax and a maximal unit of morphology". It is a language unit conveying complete lexical and semic (grammatical) meaning, the latter of which is signified in "relatively systematic ways", which can be "desinential, affixal, adpositional, stem-alternating, suprasegmental, distributional or auxiliary" (BAŃCZEROWSKi 1997a: 1165). Accordingly, e.g. the Arabic expression fi l-kitāb-i 'in the book' shall be treated as one word. Its semic meaning is that of inessivity, i.e. location in the interior of something, and definiteness. The former is conveyed by the preposition $f i$ ' 'in' and the genitive suffix $-i$; the latter by the definite article $l$-. Its lexical meaning ('being a book') is conveyed by the stem kitāb-. This notion of word differs from that traditionally used in the majority of grammars (also those of Arabic), where e.g. prepositions are treated as words with their own rection. ${ }^{4}$

However, for a number of language units it is still difficult to determine whether they are words or not. For the needs of this paper, the following solutions are adopted. Expressions such as tạta 'under' and hă $\bar{a} r i g ̆ a$ 'outside' will be treated as prepositions although they display some substantival features. Expressions such as gayr 'other than, un-', šibh 'similar to, quasi-', which are used in combination with adjectives (e.g. gayru šar 'iyyin 'illegal' lit. 'other than legal') will be treated as words as long as they inflect for case. Personal pronouns suffixed to other words, e.g. -ka in baytu-ka 'your house', or in ra'aytu-ka 'I saw you', are

(NH, e.g. buyūtun 'houses'). Its forms coincide with the feminine singular (cf. the adjective șaḡîratun 'little' in buyūtun șaḡìratun 'little houses' and imra'atun șaḡìratun 'a little woman'). In the present paper, adjectives treated as masculine singular in most standard grammars but in reality not inflecting for gender and number will be considered to have neutralized gender (NG) and neutralized number (NN), e.g. 'ašaddu 'stronger, strongest'. Both adjectives and substantives can be indefinite (INDF, e.g. baytun șaḡìrun 'a little house') or definite (DEF, e.g. albaytu ș-șaḡìru 'the little house'). For the sake of convenience, this semantic category will be referred to as 'state'.

2 The solutions proposed in this paper are a modified version of those presented in MiCHALSKI 2008.

3 In these works, the term dicton is used in this sense.

4 E.g. Matтhews 1981: 78, also Chomsкy 1970, where preposition was one of the four major syntactic categories along with noun, verb and adjective. The Arabist Beeston considered the Arabic preposition $b i$ 'with, by' to be a word, because it functions like tumma 'then' and 'ala 'on', and they are "unquestionably counted as separate words in Arabic linguistic feeling” (BEeston 1970: 30). Cf. also the discussion in BeLKIN 1975: 15-17. 
not words but parts of words. Consequently, baytuka is one word. By contrast, personal pronouns suffixed to prepositions ( $f$ ih $i$ 'in him') or particles and conjunctions ('anna-hu 'that he') will be treated as words being inflectional forms of personal pronouns.

\section{HYPOTACTIC SYNTAGMS}

One of the characteristic features of human languages is that they have both simplex and composite signs. In order for any language to be able to fulfil its communicative purposes, it must use composite signs. One reason for this is that the range of designation of some simplex signs is too narrow to designate the specific fragment of the extralingual reality a speaker wishes to speak of, whereas the range of designation of others is too wide (cf. BAŃCZEROwsKi et al. 1982: 238). Combining simplex signs into composite ones is a solution to both problems. As for the former, for instance, MWA has no simplex sign which could designate a cat and mouse at the same time (anaphora, hyperonyms, etc. do not interest us here). The sign qittatun 'a cat' designates only cats, the sign fa'run 'a mouse' designates only mice: their ranges of designation are too narrow. Only a composite sign resulting from the combination of both, qittatun wa fa 'run 'a cat and a mouse', is able to express the speaker's intent. This type of combining simplex signs into composite ones is called PARATAXIS (or coordination). The resultant composite signs are paratactic syntagms.

The second problem consists in that a given simplex sign has a range of designation which is too broad, i.e. it designates a fragment of reality which is too wide with respect to the speaker's communicative intention. For instance, in MWA, if a speaker means cats that are black, he or she will not find a simplex sign, i.e. one word, which would have the suitable range of designation. The range of designation of the simplex sign has to be narrowed, and this is achieved by forming a composite sign, namely qittatun sawdā' $u$ 'a black cat'. This composite sign does not designate all possible cats but only the black ones. This type of combining simplex signs into composite ones is called HYPOTAXIs (or subordination). The resultant composite signs are hypotactic syntagms. The two words combined into a hypotactic syntagm are bound by the relation of QUALIFICATION (BAŃCZEROWSKI 1997a: 1162; cf. also 1980, esp. 65ff). The qualified word, i.e. that which has its range of designation narrowed down, will be referred to as qualificatum or Qm. The qualifying word, i.e. that which narrows down the range of designation of the qualificatum, will be referred to as qualificator or Qr. ${ }^{5}$

The relation of qualification has important consequences for the meaning (signification)

5 A third major type of syntagm should be distinguished along with paratactic and hypotactic ones, namely appositional syntagms based on apposition. Appositional syntagms could be understood as syntagms constituted by two substantives, "where the same thing is named twice differently" (BüHLER 1990 [1934]: 351). An example of such an appositional syntagm is Muhammadun-i n-nabiyyu 'Muhammad the Prophet' or an-nabiyyu Muhammad 'Prophet Muhammad' (see also section 3). However, this question needs further clarification.

It should also be added that sentences will be treated as syntagms in this paper, with the subject being the qualificatum of the predicate. Sentential and non-sentential syntagms will not be discussed separately (see also end of section 4.7.). 
and for the range of designation of the words bound by this relation and of the resulting hypotactic syntagm. According to Bańczerowski:

the qualificator expands (broadens) the total meaning (significatum) of its qualificatum, whereby the total meaning of the resultant syntagma includes that of its constituent qualificatum [...]

the qualificator restricts (narrows down) the radius (range) of designation of its qualificatum, whereby the designation radius of the resultant syntagma is included in that of its constituent qualificatum (BAŃCZEROwSKI 1997a: 1162).

A consequence of these facts is that a hypotactic syntagm is a hyponym "with respect to its constituent qualificatum" (BAŃCZEROWSKI 1997a: 1162).

Biconstituent syntagms are not maximal syntagms since there can be syntagms composed of more than two words. This is possible because a word which is a qualificator in one syntagm can be a qualificatum in another. Also, a word which is a qualificatum in one syntagm can be a qualificator in another. That is to say that a word can be in statu qualificati and in statu qualificatoris at the same time (BAŃCZEROWSKI 1997a: 1163). For instance, in the triconstituent syntagm intensely black eyes, two biconstituent syntagms can be distinguished, black eyes and intensely black, having the following qualificational structures: (eyes, black) and (black, intensely), with the qualificatum given first and the qualificator second. The word black is in statu qualificatoris in the former syntagm while it is in statu qualificati in the latter. If we continue using the notation with the qualificatum preceding the qualificator, the qualificational structure of intensely black eyes can be represented as (eyes, black, intensely). Put somewhat metaphorically, the representations of the two biconstituent syntagms overlap on the word black. Therefore, for the goals of this paper, in the syntagm intensely black eyes, the syntagm black eyes, having the structure (eyes, black), will be called 'left-overlapping' and the syntagm intensely black, having the structure (black, intensely), will be called 'right-overlapping'. The qualificator of syntagm $_{1}$ which is 'left-overlapping' with respect to syntagm is the qualificatum of syntagm $_{2}$.

\section{ADJECTIVAL SYNTAGMS}

Identifying adjectival syntagms presupposes a criterion of identifying adjectives. The answer to the question what is an adjective in MWA is no easy thing, since morphological features are not sufficient to distinguish adjectives from substantives in this language. The criterion of gradability does not work here, since should only gradable nouns be considered adjectives, this class would not comprise words such as miṣriyyun 'Egyptian' in filmun mișriyyun 'an Egyptian film', which intuitively are adjectives. In the present paper, it is assumed that adjectives can be distinguished in MWA as a separate part of speech on the grounds of their morphological and syntactic properties. In order for a noun (nominal part of speech) to be identified as an adjective, it must meet the following requirements:

1. Capability of linearly following another noun in order to qualify it and agree with it with respect to state (definite/indefinite), number, gender and case;

Example: kabìrun 'big' in baytun kabìrun 'a big house' is an adjective; 
2. Incapability of linearly preceding another noun, while:

(i) retaining agreement (concord) with it with respect to number, gender, case, and state ${ }^{6}$;

Example: Adjectives cannot linearly precede the noun they qualify in this way (attributively) because non-grammatical constructions arise then (cf. *kabirun baytun);

and

(ii) retaining the same meaning as when following the noun;

Example: The difference between preceding and following position of the noun may result in the difference in meaning, e.g. the meaning of al-kātibu in al-kātibu Ahmadu 'the writer Ahmad' and Ahmadu l-kātibu 'the writing Ahmad, Ahmad writing', is not the same. Al-kätibu in the former is a substantive, while al-kātibu in the latter is an adjective.

Nouns without this incapability are treated as substantives and can be constituents of appositional syntagms. These are characterized by reversible word-order, e.g. Muhammadun-i n-nabiyyu 'Muhammad the Prophet' and an-nabiyyu Muhammadun 'Prophet Muhammad' (cf. footnote 5).

Nouns which can be qualified by adjectives as shown above are substantives.

The category of adjective also comprises an easily identifiable class of nouns which do not fulfil the criterion of concord completely as they do not agree with the qualified substantive with respect to gender and number. Such adjectives retain a fixed form, regardless of the gender and number of their qualificata. This form is identical with singular masculine, yet it seems justifiable to consider it to be that of neutralized gender $(\mathrm{NG})$ and neutralized number (NN). These adjectives are: (i) passive participles derived from intransitive verbs, e.g. l-mustad' 'a in (1):

$$
\begin{aligned}
& \text { al-mu'assasat-u l-mustad'a } \bar{a} \quad \text { 'alay-hă } \bar{a}^{7} \\
& \text { DEF-institution.(F).SG-NOM DEF-accused.NG.NN.NOM against-3sG.F } \\
& \text { 'the accused institution' lit. 'the institution accused against it' }
\end{aligned}
$$

The adjective l-mustad ' $\bar{a}$ 'accused', obligatorily qualified by the word 'alayh $\bar{a}$, is the passive participle of the intransitive verb istad ' $\bar{a}$ 'alā (l-mu'assasati) 'to accuse (the institution)' lit. 'to accuse against (the institution)'; (ii) adjectives with the patterns $\mathrm{fa}$ ' $\bar{u} l$ in the active sense, e.g. tamūhun 'ambitious', fa 'îl in the passive sense, e.g. qatīlun 'murdered', or mif'all with the intensifying meaning, e.g. miḡbārun 'dusty'; (iii) adjectives designating typically female properties, e.g.: hämilun 'pregnant'; (iv) elatives with the comparative or superlative meaning having the pattern 'af'al, e.g. 'ağmalu 'more/most beautiful' (including the adjectives šarrun 'worse/worst' and hayrun 'better/best'); (v) adjectives that are loanwords, e.g. müf 'mauve'; and (vi) adjectives designating a species or style indication (usually nisba-adjectives), e.g.: qahwatun turkiyyun 'a Turkish style coffee' (from BADAwI et al. 2004: 105).

Words which are identified as adjectives in this way may have functions other than attributive. These functions include:

(i) basic predicate in verbless (equative) sentences, the basic predicate always being in the nominative case, e.g. al-baytu kabirun 'The house is big';

(ii) extended predicate after special (sometimes described as auxiliary) verbs and their

${ }^{6}$ Agreement (concord) with respect to state restricts the scope of syntagms under consideration to attributive syntagms. In predicative syntagms, the qualifying adjectives can linearly precede the qualified substantive.

Syntagms exemplified in this paper represent commonly known constructions and to indicate from what source they have been excerpted seems unnecessary. 
derivates (e.g. kāna 'to be', kawnu-hā 'her being', laysa 'not to be'), the extended predicate being in the accusative case or attached to the preposition $b i$, e.g.:

$\begin{array}{lll}\text { laysa } & l \text {-bayt-u } & k a b \bar{i} r-a-n \\ \text { is.not } & \text { DEF-house.(M).SG-NOM } & \text { big.M.SG-ACC-INDF }\end{array}$

'The house is not big'.

(iii) exclamative predicate in the min-phrase, e.g.:

$\begin{array}{llll}y \bar{a} & \text { la-ka } & \min & \text { mut' } a b-i-n \\ \text { oh } & \text { PREP-2SG.M } & \text { of } & \text { tired.M.SG-GEN-INDF } \\ \text { 'How tired you are!' } & \end{array}$

(iv) secondary predicate in the accusative case (Arabic $h \bar{a} l$ ): the adjective designates a property of an entity designated by a (usually) definite substantive, a personal pronoun or an implied subject of a finite verb, without being its attribute or its basic, extended or exclamative predicate, e.g. mut 'aban 'tired' in rağa 'at Laylā mut 'abatan 'Layla returned tired';

(v) predicatoid, i.e. the qualificator in the so-called 'indirect attribute', which in this paper will be referred to as 'sententioid syntagm'. For instance, the word l-muntahiyati 'ending' is the predicatoid in the sententioid syntagm [li r-ra' 'ssi] l-muntahiyati wilāyatuhu '[for the president] whose term of office is ending',; see example (11) below for a discussion of this syntagm;

(vi) subject and object. These are typically substantival functions and therefore require substantivization of the adjective. ${ }^{9}$ Substantivization may be of various degrees, that is to say, substantivized adjectives may show more or less substantival properties (e.g. the capability of being qualified by a substantive in the genitive). For the needs of the present paper, only those substantivized adjectives will be taken into consideration which are obligatorily qualified by a substantive in the genitive and cannot be qualified attributively by other adjectives. Usually, such adjectives have neutralized gender and number, e.g.:

$$
\begin{array}{lll}
{[l a-k a]} & \underline{h} \bar{a} l i s ̦-u & \text { l-mawaddat- } i \\
\text { for-you } & \text { pure.NG.NN-NOM } & \text { DEF-love.(F).SG-GEN } \\
\text { 'Pure love to you' lit. 'For you the pure of love'. }
\end{array}
$$

(vii) adverbial. What has been traditionally described as adverbs derived from adjectives, i.e. a separate part of speech, will be treated here as adjectives used in the syntactic function of adverbial, as illustrated by sarī 'an 'quickly' in the following syntagm:

$$
\begin{aligned}
& \text { dahabat } \quad \operatorname{sar}^{-}-a-n \\
& \text { she.departed quick.NG.NN-ACC-INDF } \\
& \text { 'She departed quickly'. }
\end{aligned}
$$

${ }^{8}$ The name 'sententioid syntagm' is used here in order to reflect the desentential nature of this syntagm. Its predicatoid l-muntahiyati and its subjectoid wiläyatuhu correspond, respectively, to the basic predicate muntahiyatun and the subject wilāyatuhu in the relative clause llad̄i wiläyatuhu muntahiyatun, of which the sententioid syntagm may be presumed to be a transformation and with which it shares some syntactic characteristics.

${ }^{9}$ No historical assumptions about the process of substantivization are being made here. Substantivization is understood here as the synchronic relationship between nouns identified as adjectives and those identified as substantives in the way proposed above. 
The adjectives used in this function show neutralized gender and number. They are always indefinite and stand in the accusative case.

\section{SYNTAGMS AND DIMENSIONS}

Properties that characterize syntagms and which can be reasonably compared with one another, i.e. are of the same nature, or homogeneous, are classified in sets called dimensions. Every such dimension shall contain the property INDEFINIBILITY because a particular syntagm may be uncharacterizable with regard to a particular dimension (e.g. a non-adjectival syntagm will show this property with respect to many dimensions to be presented here). In what follows, nine dimensions are proposed. However, it is certain that for an exhaustive characterization of biconstituent hypotactic adjectival syntagms in MWA, which are fairly complex objects, some other dimensions could be added.

\subsection{QUALIFICATIONAL STATUS OF THE ADJECTIVE}

Dimension 1, qualificational status of the adjective, shall reflect the distinction between:

(i) those with an adjectival qualificator (adjectivo-qualificatorial syntagms),

(ii) syntagms with an adjectival qualificatum (adjectivo-qualificatal syntagms),

(iii) and those with both adjectival qualificatum and qualificator (bi-adjectival syntagms).

For instance, the syntagm in (6) is an adjectivo-qualificatorial syntagm:

$$
\begin{array}{ll}
\text { 'ağal-u-n } & \text { tawīl-u- } n \\
\text { term.(M).sG-NOM-INDF } & \text { long.M.SG-NOM-INDF } \\
\text { 'a long term' } &
\end{array}
$$

The syntagm in (7) is an adjectivo-qualificatal syntagm:

$$
\begin{array}{ll}
\text { tawīl- } u \quad l \text {-'ağal-i } \\
\text { long.M.SG-NOM } & \text { DEF-term.(M).SG-GEN } \\
\text { 'long-termed' lit. 'long of term' }
\end{array}
$$

A bi-adjectival syntagm is exemplified in (8):

$$
\begin{array}{lc}
\text { da } \bar{a} h i b-a t-u-n & \operatorname{sar} \bar{\imath}-a-n \\
\text { going-F.SG-NOM-INDF } & \text { quick.NG.NN-ACC-INDF } \\
\text { 'going quickly (said of a female person)' }
\end{array}
$$

Consequently, the dimension contains the following properties:

\{ADJECTIVO-QUALIFICATORIALITY, ADJECTIVO-QUALIFICATALITY, BI-ADJECTIVALITY, ...

\subsection{PARTIORATIVE MEMBERSHIP OF THE CO-CONSTITUENT OF THE ADJECTIVE}

Dimension 2, partiorative $e^{10}$ membership of the co-constituent of the adjective, enables adjectival syntagms to be characterized as regards the part of speech to which the co-constit-

\footnotetext{
${ }^{10}$ The term 'partiorative' means 'relating to the parts of speech' (from Latin partes orationis).
} 
uent of its adjectival constituent belongs. Adjectival syntagms may take one of the following properties:

\{CO-CONSTITUENCY WITH A SUBSTANTIVE, CO-CONSTITUENCY WITH A VERB, CO-CONSTITUENCY WITH A PRONOUN, CO-CONSTITUENCY WITH A NUMERAL, CO-CONSTITUENCY WITH AN ADJECTIVE, $\ldots\}$

Syntagms (6) and (7) show CO-CONSTITUENCY with A substantive, while syntagm (5) shows CO-CONSTITUENCY WITH A VERB. Evidently, syntagms showing BI-ADJECTIVALITY with respect to Dimension 1 will always show the property of CO-CONSTITUENCY WITH AN ADJECTIVE with respect to Dimension 2.

\subsection{INTRACATEGORY DIFFERENTIATION OF THE ADJECTIVAL CONSTITUENT}

The category of adjective is divisible into two major subcategories, elative (with comparative and superlative meaning) and positive. To which of these two subcategories the adjectival constituent of a syntagm belongs will be reflected in Dimension 3, intracategory differentiation of the adjectival constituent.

Syntagms having an elative as its qualificatum show ELATIVAL QUALIFICATALITY. Syntagms having an elative as their qualificator show ELATIVAL QUALIFICATORIALITY. Syntagms having a positive adjective as their qualificatum show POSITIVAL QUALIFICATALITY. Syntagms having a positive adjective as their qualificator show POSITIVAL QUALIFICATORIALITY.

Bi-adjectival syntagms will be characterized with respect to both the qualificatum and the qualificator. Thus, the following properties will be added to this dimension: ELATIVAL QUALIFICATALITY WITH ELATIVAL QUALIFICATORIALITY, POSITIVAL QUALIFICATALITY WITH POSITIVAL QUALIFICATORIALITY, ELATIVAL QUALIFICATALITY WITH POSITIVAL QUALIFICATORIALITY, and POSITIVAL QUALIFICATALITY WITH ELATIVAL QUALIFICATORIALITY. Consequently, the dimension will contain the following properties:

\{ELATIVAL QUALIFICATALITY, ELATIVAL QUALIFICATORIALITY, POSITIVAL QUALIFICATALITY, POSITIVAL QUALIFICATORIALITY, ELATIVAL QUALIFICATALITY WITH ELATIVAL QUALIFICATORIALITY, POSITIVAL QUALIFICATALITY WITH POSITIVAL QUALIFICATORIALITY, ELATIVAL QUALIFICATALITY WITH POSITIVAL QUALIFICATORIALITY, POSITIVAL QUALIFICATALITY WITH ELATIVAL QUALIFICATORIALITY, ... $\}$

An example of a syntagm showing ELATIVAL QUALIFICATALITY is given in (9):

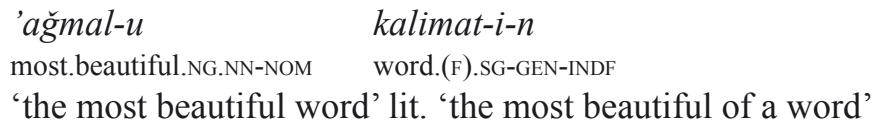

An example of a syntagm showing POSITIVAL QUALIFICATALITY WITH ELATIVAL QUALIFICATORIALITY is:

$$
\begin{aligned}
& \text { tāni } \quad \text { 'ahamm- } i \\
& \text { second.NG.NN.NOM most.important.NG.NN-GEN } \\
& \text { 'the second most important [centre]' }
\end{aligned}
$$

[markaz-i-n]

centre.(M).SG-GEN-INDF

Positive adjectives can be further subdivided into participial adjectives, i.e. positive adjectives that are participles, and non-participial adjectives, i.e. the remaining ones. The former can be divided into passive participial adjectives and active participial adjectives. 
Both active and passive participial adjectives are divisible into those derived from transitive verbs and those derived from intransitive verbs. This further characterization of positival adjectives will not be taken into consideration here.

\subsection{KIND OF MORPHOLOGICAL INDICATORS}

That two constituents are bound by the relation of qualification into a syntagm can be signalled morphologically in various ways. Qualification may be indicated by means of concord (agreement) between the constituents or rection (government) of one of the constituents with respect to the other. However, it should be stressed here that a relationship of morphological character between two words does not necessarily indicate qualification between them. For instance, in constructions involving the 'sententioid syntagm' (traditionally termed 'indirect attribute'), as exemplified in (11), there is concord between the words li $r$-ra 'is $s i$ 'for the president' and l-muntahiyati 'ending' with respect to state and case (both words are definite and in the genitive).

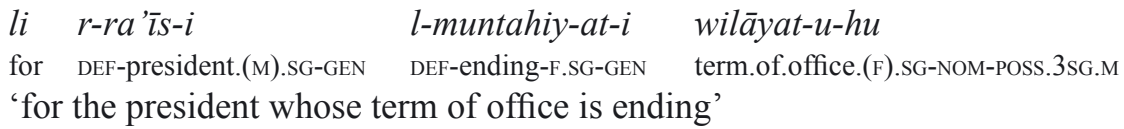

However, these two words cannot be said to be bound by the relation of qualification (specifically, that $l i$ r-ra' 'isi is qualified by l-muntahiyati) because it is the 'term of office' that is ending, not the 'president' himself. The concord between these words does not indicate qualification between them; it only indicates that li $r$-ra' $\bar{l} s i$ is qualified by the entire relative 'sententioid syntagm' l-muntahiyati wilāyatuhu 'whose term of office is ending'.

While morphological indicators not indicating qualification between words seem to be a rather infrequent phenomenon, qualification without morphological indicators (with no concord or rection) occurs very often. For instance, no morphological indicators point to qualification between the constituents of the syntagm qā'imun hun $\bar{a}$ 'standing here' (the adverb hunā 'here' is uninflected'). Such a lack of morphological indicators will be referred to as lexical junction (cf. BAŃCZEROWSKI 1988: 54), because the constituents hold together on the strength of their lexical meaning (their linear order and contiguity, however, seem to be relevant as well).

Another important observation to be made here is that the relationship between qualification and morphology has not been properly described in Arabic studies. Arabists who have dealt with the problems of Arabic syntax seem not to have sufficiently kept morphology apart from qualification. Frequently, the terminology used in works describing the syntax of MWA is not employed with due precision, sometimes not at all explained. The picture one gets when trying to understand the relations obtaining within syntagms of MWA is made more chaotic by the diversity of terminology in the works of different authors. Three different analyses of the 'sententioid syntagm', i.e. indirect attribute exemplified in (11), to be presented here will suffice to illustrate this point. As regards the adjective in this construction, the grammar of Badawi et al. distinguishes between 'structurally qualifies' and 'logically qualifies', while also using the expression 'qualifies only indirectly' (BADAwI et al. 
2004: 114). El-Ayoubi et al. (2001) use terms such as 'Bezugsnomen' and 'Abhängigkeit vom Bezugsnomen' when referring to morphosyntactic relations. With reference to semantic relations, they speak of the 'Subjekt' of an 'Adjektivgruppe' which is not identical to its 'Bezugnomen' in this construction (EL-AyouBi et al. 2001: 186). The analysed syntagm, called by them "Satzadjektiv", is characterized as follows: "Beim Satzadjektiv qualifiziert das Adjektiv primär sein Subjekt” (2001: 36), i.e. l-muntahiyati qualifies wilāyatuhu. But it seems to be assumed that the adjective also qualifies the preceding noun [scil. li $r$-ra 'îsi] because one reads that "das Adjektiv meist auch ohne die jeweilige Ergänzung durch das eigene Subjekt [...] bereits eine zutreffende Qualifikation des Kernnomens [scil. li r-ra'̌isi] darstellt" (2001: 36). Finally, Paradela Alonso says that the adjective here is a complex adjective ("adjetivo complejo") which "in reality describes a quality of a subpart of its first or apparent qualificatum' ("en realidad está adjetivando a una subparte [...] de su calificado primero o aparente" (PARAdELA Alonso 2005 [1998]: 43). The terminological apparatus introduced in section 2 of this paper is aimed at enabling a clearer and a more adequate description of the syntagms in MWA.

If the constituents of a syntagm are bound by rection or concord, this syntagm will be said to show the property of RECTIONALITY or CONCORDIALITY, respectively. In order to reflect various kinds of rection and concord, various kinds of rectionality and concordiality will be distinguished for this dimension. Some syntagms show more than one kind of concord or concord and rection simultaneously. For these reasons, corresponding properties are added. This dimension also contains the property of LEXICO-JUNCTIONALITY, which characterizes syntagms based on lexical junction. An analysis of the morphological relations within biconstituent hypotactic adjectival syntagms in MWA conducted in MicHALSKI 2008 has shown that for the description of this language, the dimension under consideration should contain the following properties:

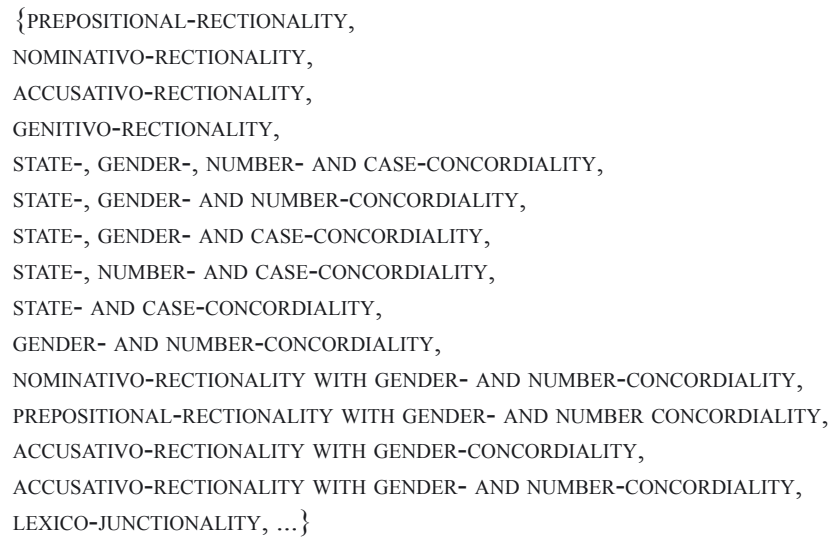

What follows are examples of syntagms showing each property:

PREPOSITIONAL-RECTIONALITY: l-mustad ' $\bar{a}$ 'alayh $\bar{a}$ 'accused' in (1). NOMINATIVO-RECTIONALITY: az-zawğatu hâmilun 'The wife is pregnant'.

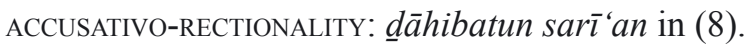
GENITIVO-RECTIONALITY: tawìlu l-'ağali in (7). STATE-, GENDER-, NUMBER- AND CASE-CONCORDIALITY: 'ağalun țawīlun in (6). 
STATE-, GENDER- AND NUMBER-CONCORDIALITY:

$$
\begin{array}{lll}
\text { al-'aši “at-u } & \text { fawqa } & \text { l-banafsağiyy-at- } i \\
\begin{array}{l}
\text { DEF-rays.NH.PL-NOM } \\
\text { 'ultra-violet rays' }
\end{array} & & \text { DEF-violet-NH.PL-GEN }
\end{array}
$$

(The genitive case of the adjective is due to the preposition fawqa.)

STATE-, GENDER- AND CASE-CONCORDIALITY:

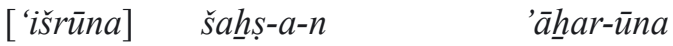

$$
\begin{aligned}
& \text { twenty.NOM person.(M).SG-ACC-INDF other.M-PL.NOM.INDF } \\
& \text { '[twenty] other persons' }
\end{aligned}
$$

STATE-, NUMBER- AND CASE-CONCORDIALITY,

$$
\begin{aligned}
& \text { al-'arba' 'ūna ['ām-a-ni] [l-mādiy-at-u } \\
& \text { DEF-forty.NOM year.(M).SG-ACC-INDF DEF-past-NH.PL-NOM } \\
& \text { 'the past forty [years]' }
\end{aligned}
$$

(The numeral 'forty' is taken here to be lexically plural.)

STATE- AND CASE-CONCORDIALITY: az-zawğatu l-hāmilu 'the pregnant wife'.

GENDER-AND NUMBER-CONCORDIALITY: l-muntahiyati wilāyatuhu 'whose term of office is ending' in (11).

NOMINATIVO-RECTIONALITY WITH GENDER- AND NUMBER-CONCORDIALITY:

$$
\begin{array}{ll}
\text { al-bayt-u } & \text { kabìr-u- } n \\
\text { DEF-house.(M).SG-NOM } & \text { large.M.SG-NOM-INDF } \\
\text { 'the house [is] large' } &
\end{array}
$$

PREPOSITIONAL-RECTIONALITY WITH GENDER- AND NUMBER CONCORDIALITY: yā laka min mut 'abin 'How tired your are!' in (3).

ACCUSATIVO-RECTIONALITY WITH GENDER-CONCORDIALITY:

$$
\begin{aligned}
& \text { ğa 'a [r-riğâl-u } \quad \text { rākiḍ-ìna } \\
& \text { came.3SG.M DEF-men.(M).PL-NOM running.M-PL.ACC } \\
& \text { '[the men] came running' }
\end{aligned}
$$

The plural secondary predicate rākidinna qualifies the verb $g^{g} \bar{a}$ 'a, which is singular because of its preceding, not following the subject r-riğâlu.

ACCUSATIVO-RECTIONALITY WITH GENDER- AND NUMBER-CONCORDIALITY:

$$
\begin{aligned}
& \text { dahabat } \quad \text { musri'-at-a-n } \\
& \text { she.departed hurrying-F.SG-ACC-INDF } \\
& \text { '(she) departed in a hurry' lit. 'hurrying' }
\end{aligned}
$$

LEXICO-JUNCTIONALITY: $q \bar{a}$ 'imun hunā 'standing here'.

A biconsituent hypotactic syntagm with morphological indicators pointing to qualification may also be characterized with respect to whether it is the qualificator that is governed by, or agrees with, the qualificatum or, by contrast, whether it is the qualificatum that is governed by, or agrees with, the qualificator. Since in MWA the former holds true for all syntagms, there is no possibility of differentiating them in this regard. 


\subsection{LINEAR ORDER OF THE CONSTITUENTS}

Dimension 5, linear order of the constituents, makes it possible to characterize syntagms in terms of the linear order of their qualificators and qualificata. Syntagms in which the qualificatum linearly precedes the qualificator will be called Qm-fronted syntagms. Some of the syntagms belonging to this category may have the word order of their constituents reversed resulting in a synonymous syntagm, which differs, if at all, only in style or emphasis, while others may not be subject to such an operation. The former, let us call them reversibly Qm-fronted, are exemplified by the syntagm al-hayātu ğamilatun 'Life is beautiful' (which has its synonymous counterpart in ğamilatun-i l-hayātu), the latter, let us call them irreversibly Qm-fronted, are exemplified in tawīlu l-'ağali (7), for which such a counterpart does not exist.

Syntagms in which the qualificator linearly precedes the qualificatum will be referred to as Qr-fronted syntagms. Like Qm-fronted syntagms above, some Qr-fronted syntagms may have the word order of their constituents reversed resulting in a synonymous syntagm, with only style or emphasis being possibly changed. Other Qr-fronted syntagms cannot be subject to this operation. The former, let us call them reversibly Qr-fronted, may be exemplified by the syntagm ğamīlatun-i l-hayātu 'Life is beautiful' (which has its synonymous counterpart in al-hayātu ğamīlatun). The latter, irreversibly Qr-fronted, are exemplified by [li r-ra'`̄si] l-muntahiyati wilāyatuhu '[for the president] whose term of office is ending', for which such a counterpart does not exist (cf. *[li r-ra'’̄si] wilāyatuhu l-muntahiyati]. Thus, this dimension contains the following properties:

\{REVERSIBLE QM-FRONTEDNESS, IRREVERSIBLE QM-FRONTEDNESS, REVERSIBLE QR-FRONTEDNESS, IRREVERSIBLE QR-FRONTEDNESS, ...\}

\subsection{LINEAR CONTIGUITY OF THE CONSTITUENTS}

Dimension 6, linear contiguity of the constituents, reflects in what form a syntagm has occurred in a specific text: whether the constituents are linearly contiguous or discontiguous, i.e. with a disjoining unit between them. However, this dimension should also make it possible to distinguish (i) contiguous syntagms that have a synonymous discountiguous counterpart and (ii) contiguous syntagms that do not have it, on one hand, and (iii) discontiguous syntagms that have synonymous contiguous counterparts and (iv) discontiguous syntagms that do not have them, on the other hand. Therefore, the following properties are proposed for this dimension:

\{DISJOINABLE CONTIGUITY, UNDISJOINABLE CONTIGUITY, CONJOINABLE DISCONTIGUITY, UNCONJOINABLE DISCONTIGUITY, ...\}

A syntagm that shows DISJOINABLE CONTIGUITY is one that has a synonymous discountiguous counterpart. An example is given in (18):

$$
\begin{array}{lll}
{[\text { silāhh-u- } n]} & b \bar{a} l i \bar{g}-u & t-t a{ }^{\prime} \underline{t} \bar{r}-i \\
\text { weapon.(M).SG-NOM-INDF } & \text { great.M.SG-NOM } & \text { DEF-impact.(M).SG-GEN } \\
\text { '[weapon of] great impact' lit. '[weapon] great of impact' }
\end{array}
$$


Its synonymous linearly dicontiguous counterpart is bāliḡu [l-quwwati wa] t-ta'tīiri in (19):

$$
\begin{array}{llll}
{[\text { silāhl-u-n] }} & \text { bāliḡ-u } & {[l-q u w w a t-i w a]} & t-t a ' t \bar{l} r-i \\
\text { weapon.(M).SG-NOM-INDF } & \text { great.M.SG-NOM } & \text { DEF-power.(F).SG-GEN and } & \text { DEF-impact.(M).SG-GEN } \\
\text { '[weapon of] great [power and] impact' lit. '[weapon] great [of power and] impact' }
\end{array}
$$

The word $l$-quwwati is a paratactic co-constituent of the qualificator $t$-ta'tīri. It should be noted here that in order for the syntagm bāliḡ $u$-ta 'tīiri to have a synonymous linearly dicontiguous counterpart, the disjoining unit in this counterpart must be a paratactic co-constituent of the qualificator or of the qualificatum. Moreover, the conjunction wa 'and' is required. In other syntagms the disjoining unit may be of any kind with no conjunction needed. For instance, the synonymous linearly discontiguous counterpart of the syntagm al-ḥayātu ğamīlatun 'Life is beautiful' may be al-hayātu [fì Miṣra] ğamīlatun 'Life in Egypt is beautiful', where fi Mișra 'in Egypt' is not a paratactic co-constituent of the qualificator or the qualificatum. The property of UNDISJOINABLE CONTIGUITY characterizes syntagms that do not have synonymous discontiguous counterparts, e.g. the syntagms mustad ' $\bar{a}$ 'alayhā in (1) and l-muntahiyati wilāyatuhu in (11).

The property of CONJOINABLE DISCONTIGUITY characterizes discontiguous syntagms that have synonymous contiguous counterparts, e.g. bāliḡ $u$ [l-quwwati wa] t-ta'tīiri in (19) because it has its contiguous counterpart in the syntagm bāliḡu t-ta'tīiri in (18). Syntagms that show UNCONJOINABLE DISCONTIGUITY are syntagms that do not have synonymous contiguous counterparts. An example is given in (20):

$$
\begin{aligned}
& \text { bayt-u [l-mu'allim-i] l-kabìr-u } \\
& \text { house.(M).SG-NOM DEF-teacher.(M).SG-GEN DEF-big.M.SG-NOM } \\
& \text { '[the teacher's] big house' }
\end{aligned}
$$

A hypothetical contiguous counterpart of (20), *baytu l-kabīru, is non-grammatical. In order for it to be grammatical the substantive must have the definite article, cf. al-baytu l-kabiru.

\subsection{SYNTACTIC FUNCTION OF THE ADJECTIVE IN STATU QUALIFICATORIS}

Adjectival syntagms can be characterized with respect to the syntactic function of the adjectival qualificator. Therefore, Dimension 7, syntactic function of the adjective in statu qualificatoris, will be proposed here. The properties concerning the syntactic function of the adjective in statu qualificatoris, e.g. functioning as attribute, extended predicate, etc., will be extended so as to refer to syntagms. The following syntactic functions will be taken into account here: subject, basic predicate, extended predicate, secondary predicate, exclamative predicate (all introduced in section 3), direct object, indirect object, internal object (Arabic maf'ül muțlaq), and adverbial. Since the so-called indirect attribute is a sentence-like, or 'sententioid', syntagm, its qualificatum is considered to have the syntactic function of 'sub- 
jectoid', and its qualificator that of 'predicatoid'. The dimension proposed here contains the following properties:

\{QR-ATTRIBUTIVITY ${ }^{11}$, QR-BASIC PREDICATIVITY, QR-EXTENDED PREDICATIVITY, QR-SECONDARY PREDICATIVITY, QREXCLAMATIVE PREDICATIVITY, QR-PREDICATOIDNESS, QR-DIRECT OBJECTIVITY, QR-INDIRECT OBJECTIVITY, QR-INTERNAL OBJECTIVITY, QR-ADVERBIALITY, $\ldots\}$

Since the subject does not qualify any other word in a sentence, in other words, it is the qualificatum absolutum (cf. BAŃCZEROWSKI et al. 1982: 247 and 270), this dimension does not contain the property of QR-SUBJECTIVITY. The same holds true for the 'subjectoid', which is the qualificatum absolutum in the 'sententioid syntagm'.

Thus, for instance, the syntagm baytun kabirun 'a large house' is a syntagm showing QR-ATTRIBUTIVITY, since the adjective which is the qualificator functions as an attribute (in adjectival attribution). The syntagm l-muntahiyati wilayatuhu is a syntagm with the property of QR-PREDICATOIDNESS. The syntagm țawìlu l-'ağali 'long-term', lit. 'long of term', shows the property of INDEFINIBILITY since it is a syntagm with no adjective in statu qualificatoris.

Finally, let us remark that all syntagms that show QR-BASIC PREDICATIVITY, QR-EXTENDED PREDICATIVITY Or QR-EXCLAMATIVE PREDICATIVITY with respect to this dimension are sentences. For example, both al-baytu kabirun 'The house is big' in (15), which shows QR-BASIC PREDICATIVITY, and laysa [l-baytu] kabiran '[The house] is not big' in (2), which shows QR-EXTENDED PREDICATIVITY, are sentences. For this reason, it seems unnecessary to propose a separate dimension with respect to which syntagms could be differentiated into sentential and nonsentential.

\subsection{SYNTACTIC FUNCTION OF THE ADJECTIVE IN STATU QUALIFICATI}

Dimension 8, syntactic function of the adjective in statu qualificati, makes it possible to characterize the syntagms with respect to the syntactic function of the adjectival qualificatum. The properties concerning the syntactic function of the adjective in statu qualificati will be extended so as to refer to syntagms. As substantivized adjectives may function as subjects and words with these syntactic functions can be qualificata, this dimension will contain an additional property, that of QM-SUBJECTIVITY. ${ }^{12}$

In order for a syntagm to be characterized with respect to this dimension, it is necessary to determine what syntactic function its adjective in statu qualificati has. In most cases, namely with the exception of syntagms with their qualificata being subjects, this can be made only by taking into consideration the qualificatum of the syntagm which is 'left-overlapping' with respect to the syntagm to be characterized. (Let us recall here that the qualificator of syntagm ${ }_{1}$ which is 'left-overlapping' with respect to syntagm ${ }_{2}$ is the qualificatum of syntagm ${ }_{2}$ ). Hence, it can be said that the properties of Dimension 8 are properties going

${ }^{11}$ Qr-attributivity does not only refer to adjectives qualifying in adjectival attribution (e.g. baytun kabìrun

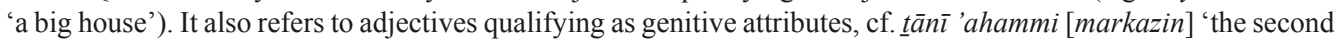
most important [centre]' in (10).

${ }^{12}$ Although grammatically possible (cf. a hypothetical li r-ra'ìsi l-muntahiyati 'ūlā wilāyātihi 'for the president whose first term of office [lit. 'the first of his terms of office'] is ending'), sententioid syntagms with adjectives functioning as their subjectoids seem not to be in use. Therefore, this dimension will not contain the property of QM-SUBJECTOIDNESS. 
beyond the scope of a particular biconstituent syntagm. This, however, does not concern syntagms the qualificata of which are subjects: their qualificata are never in statu qualificatoris in other syntagms, therefore such syntagms do not have 'left-overlapping syntagms'. The dimension proposed here will contain the following properties:

\{QM-ATTRIBUTIVITY, QM-BASIC PREDICATIVITY, QM-EXTENDED PREDICATIVITY, QM-SECONDARY PREDICATIVITY, QM-EXCLAMATIVE PREDICATIVITY, QM-PREDICATOIDNESS, QM-DIRECT OBJECTIVITY, QM-INDIRECT OBJECTIVITY, QM-INTERNAL OBJECTIVITY, QM-ADVERBIALITY, QM-SUBJECTIVITY, ... $\}$

Thus, for instance, the syntagm țawìlu l-'ağali 'long-term' as used in istițmārun țawìlu l-'ağali 'a long-term investment', lit. 'an investment long of term', shows QM-ATTRIBUTIVITY because it is a syntagm with the adjective in statu qualificati which in the left-overlapping syntagm istitmārun tawillu functions as the attribute of the word istitmārun. The syntagm țawìlu l-'ağali used in al-istitmāru tawìlu l-'ağali 'The investment is a long-term [one]' shows QM-BASIC PREDICATIVITY because its adjective in statu qualificati is the basic predicate in its left-overlapping syntagm (with the subject al-istitmāru).

\subsection{OMISSIBILITY OF THE QUALIFICATOR OF THE ADJECTIVE}

Dimension 9, degree of the omissibility of the qualificator of the adjective, enables adjectival syntagms to be characterized in terms of the grammatical admissibility of the omission of a qualificator ${ }^{13}$ of the adjective. Put differently, this dimension highlights the fact that the qualificator of the adjective in some syntagms can be omitted resulting in a grammatical expression. The syntagm is then reduced to a word (formerly its qualificatum). Similarly to Dimension 8, the properties grouped in Dimension 7 go beyond the scope of a particular biconstituent syntagm, because the omissibility of the qualificator of the adjective in a syntagm can be established only by taking into consideration its left-overlapping syntagm. This does not concern syntagms the qualificata of which are subjects: their qualificata are never in statu qualificatoris in other syntagms; therefore, such syntagms do not have 'left-overlapping syntagms'. The omissiblity of the qualificator of such a syntagm is determinable on the grounds of the grammaticality of the qualificatum to which the syntagm is reduced, cf. the irreducibility of hālișu l-mawaddati in (4) to *hălișu, which is non-grammatical.

Only adjectivo-qualificatal and bi-adjectival syntagms will take a definite property with respect to this dimension, while adjectivo-qualificatorial syntagms will always take the property of INDEFINIBILITY. For the dimension under consideration, the following properties will be proposed:

\{MEANING-PRESERVING REDUCIBILITY TO A WORD, MEANING-CHANGING REDUCIBILITY TO A WORD, SEMANTICALLY CONDITIONED IRREDUCIBILITY TO A WORD, MORPHOLOGICALLY CONDITIONED IRREDUCIBILITY TO A WORD, ... $\}$

A syntagm that shows MEANING-PRESERVING REDUCIBILITY TO A WORD is one which, after its qualificator has been omitted, results in an adjective (formerly its qualificatum) which, being unqualified, qualifies the qualificatum of the left-overlapping syntagm, with no (substantial) change in the meaning of the original expression entailed. An example is t-tawìlu l-qāmati 'tall of height' as used in ar-rağulu t-tawìlu l-qāmati 'the man tall of height' because its qualificator, l-qāmati 'of height', can be omitted and this results in the word t-tawìlu quali-

\footnotetext{
${ }^{13}$ Along with qualificators of this qualificator, if there are any.
} 
fying ar-rağulu, i.e. the qualificatum of the left-overlapping syntagm, without making the entire left-overlapping syntagm, viz. ar-rağulu t-tawìlu 'the tall man', non-grammatical or entailing a change of the meaning.

The property of MEANING-CHANGING REDUCIBILITY TO A WORD characterizes e.g. the syntagm t-țawìlu l-bāli 'patient' lit. 'long of mind', as used in ar-rağulu t-tawìlu l-bāli 'the patient man' lit. 'the man long of mind' because its qualificator, $l-b \bar{a} l i$ 'of mind', can be omitted and this results in the word t-tawìlu qualifying ar-rağulu, i.e. the qualificatum of the left-overlapping syntagm, without making the entire left-overlapping syntagm, viz. arrağulu t-țawìlu 'the tall man', non-grammatical. The meaning, however, is changed.

A syntagm that shows SEMANTICALLY CONDITIONED IRREDUCIBILITY TO A WORD is one from which the qualificator cannot be removed, without its left-overlapping syntagm being thus made non-grammatical for semantic reasons. Thus, for instance, the syntagm l-katīiru l-māli 'wealthy' lit. 'abundant in wealth' as used in ar-rağulu l-katīiru l-māli 'the wealthy man' lit. 'the man abundant in wealth' cannot be reduced to a word because if its qualificator, $l$-māli 'of wealth', was removed, its left-overlapping syntagm would be non-grammatical for semantic reasons, cf. *ar-rağulu l-katīiru 'the abundant man'.

A syntagm that shows MORPHOLOGICALLY CONDITIONED IRREDUCIBILITY TO A WORD is one from which the qualificator cannot be removed, without its left-overlapping syntagm being thus made non-grammatical for morphological reasons. An example is tawìlu l-qāmati 'tall of height' as used in rağulun țawìlu l-qāmati 'a man tall of height', because if it is reduced to tawilu, its left-overlapping syntagm becomes non-grammatical for morphological reasons, cf. *rağulun tawìlu (intended to mean 'a tall man', which would have to be rağulun tawìlun).

\section{CHARACTERIZATION OF SYNTAGMS AND SYNTAGM TYPES}

Properties of syntagms can be used for conducting the characterization of any biconstituent hypotactic adjectival syntagm. This characterization is conceived of as the set of all properties a syntagm shows with respect to all dimensions (nine in the present proposal). Thus, for instance, the syntagm țawìlu l-qāmati 'tall of height' as used in rağulun tawīlu l-qämati 'a man tall of height' has the following characterization:

Dimension 1. Qualificational status of the adjective:

ADJECTIVO-QUALIFICATALITY

Dimension 2. Partiorative membership of the co-constituent of the adjective:

CO-CONSTITUENCY WITH A SUBSTANTIVE

Dimension 3. Intracategory differentiation of the adjectival constituent:

POSITIVAL QUALIFICATALITY

Dimension 4. Kind of morphological indicators:

GENITIVO-RECTIONALITY

Dimension 5. Linear order of the constituents: IRREVERSIBLE QM-FRONTEDNESS

Dimension 6. Linear contiguity of the constituents: DISJOINABLE CONTINUITY 
Dimension 7. Syntactic function of the adjective in statu qualificatoris:

INDEFINIBILITY

Dimension 8. Syntactic function of the adjective in statu qualificati:

QM-ATTRIBUTIVITY

Dimension 9. Omissibility of the qualificator of the adjective: MORPHOLOGICALLY CONDITIONED IRREDUCIBILITY TO A WORD

Characterizations of syntagms enable syntagms to be compared with one another and their distance to be calculated in terms of the number of dimensions with respect to which they show different properties. Besides characterizations, the dimensions can also be used for categorization of syntagms: every property specifies a category which is a type, i.e. a set of all syntagms that show this property. Thus, for instance, the property of ADJECTIVO-QUALIFICATALITY specifies a category with the following elements given here by way of example: țawìlu l-qāmati, aț-țawīlu l-qāmati, 'ağmalu kalimatin, etc. The property of MORPHOLOGICALLY CONDITIONED IRREDUCIBILITY TO A WORD specifies a category with the following elements given here by way of example: [rağulun] țawìlu l-qāmati, [țānī] 'ahammi markazin, [laka] hāliṣu l-mawaddati, etc.

\section{CONCLUSION}

The properties proposed here and dimensions into which they are grouped enable biconstituent hypotactic adjectival syntagms in MWA to be described in a systematic way. The set of dimensions could be expanded so as to make it possible to characterize other syntagms, not only the adjectival ones. It also seems that, with necessary modifications and additions, the dimensions could be used for comparing syntagms across languages (e.g. translative equivalents). This requires, among other things, a more universal definition of the adjective and coherent descriptions of the morphology in these languages.

\section{REFERENCES}

Badawi Elsaid, CArter Michael G., Gully Adrian. 2004. Modern Written Arabic. A Comprehensive Grammar. New York: Routledge.

BańcZerowski Jerzy. 1980. Systems of Semantics and Syntax. A Determinational Theory of Language. Warszawa-

Poznań: Państwowe Wydawnictwo Naukowe.

BAŃCZEROWSKI Jerzy. 1988. “A Contribution to the Theory of Concord.” In: BASAJ et al. 1988: 53-69.

BańcZerowski Jerzy. 1997a. “A Theory of Rection.” In: Hickey \& Puppel 1997: 1159-1182.

BAŃCZEROwSKi Jerzy. 1997b. “Aspects of General Morphology. A Tentative Axiomatic Approach.” Studia Germanica Posnaniensia 33, 13-46.

Bańczerowski Jerzy, Pogonowski Jerzy, ZGóŁKa Tadeusz. 1982. Wstęp do językoznawstwa (An Introduction to Linguistics). Poznań: Wydawnictwo Naukowe Uniwersytetu im. Adama Mickiewicza w Poznaniu.

BASAJ Mieczysław et al. (eds.). 1988. Wokót języka. Rozprawy i studia poświęcone pamięci Profesora Mieczysława Szymczaka (About Language. Papers in Memory of Professor Mieczysław Szymczak). Wrocław-WarszawaKraków-Gdańsk-Łódź: Zakład Narodowy im. Ossolińskich. Wydawnictwo Polskiej Akademii Nauk. BeEston Alfred F.L. 1970. The Arabic Language Today. London: Hutchinson University Library. BeLkin V.M. 1975. Arabskaja leksikologija. Moskva: Izdatel'stvo Moskovskogo Universiteta. 
BüHLER Karl. 1990. Theory of Language. The Representational Function of Language. Transl. D.F. Goodwin. Amsterdam-Philadelphia: John Benjamins. [Originally Sprachtheorie, Jena-Stuttgart: Gustav Fischer Verlag, 1934.]

Chomsky Noam. 1970. "Remarks on Nominalization.” In: Jacobs \& Rosenbaum 1970: 184-221.

EL-Ayoubi Hashem, Fischer Wolfdietrich, LANGer Michael. 2001. Syntax der arabischen Schriftsprache der Gegenwart. Teil I, Band 1. Das Nomen und sein Umfeld. Wiesbaden: Reichert.

Hickey Raymond, Puppel Stanisław. (eds.). 1997. Language History and Language Modelling: a Festschrift for Jacek Fisiak on His 60th Birthday. Vol. 2. Berlin-New York: Mouton de Gruyter.

JACOBS Roderick A., RosenBAum Peter S. (eds.). 1970. Readings in English Transformational Grammar. Waltham, Mass: Ginn.

Matthews Peter H. 1981. Syntax. Cambridge: Cambridge University Press.

Michalski Marcin. 2008. A Typology of Biconstituent Hypotactic Adjectival Syntagms in Modern Written Arabic. Poznań: Unpublished doctoral dissertation.

Paradela Alonso Nieves. 2005. Manual de sintaxis árabe. Madrid: Universidad Autónoma de Madrid [1st edn. 1998].

Allatum die 31 mensis Martii anno 2009 